\title{
A Cladistic Analysis of Inaequalium (Coscarón \& Wygodzinsky, 1984), with Information on Geographical Distribution (Diptera: Simuliidae)
}

\author{
MNStrieder $/^{+}$, V Py-Daniel*
}

\author{
Laboratório de Entomologia, Centro de Ciências da Saúde, Universidade do Vale do Rio dos Sinos, Av. Unisinos 950, 93001-970 \\ São Leopoldo, RS, Brasil *Instituto Nacional de Pesquisas da Amazônia, Manaus, AM, Brasil
}

The black flies of the genus Inaequalium present a Neotropical distribution, with Panama at the northern limit, and the Argentinian pampas at the southern, but do not occur in the Central Amazon. This study offers a cladistic analysis establishing a hypothesis of relationships between the species of Inaequalium. A total of 37 characters have been considered in order to establish the hypothetic phylogenetic relationships. Cerqueirellum (Py-Daniel, 1983) was considered as outgroup. Data were analyzed using Henning 86 version 1.5. Wich the ie* command and implicit enumeration a unique possible cladogram was obtained in Inaequalium with 52 steps, and a CI of 0.76 and RI of 0.81 . Two well-defined clades was obtained in the resulting cladogram, the "botulibranchium" species-group, includes I. travassosi, I. souzalopesi, I. botulibranchium and I. petropoliense, and the "inaequale" species-group, includes I. rappae, I. nahimi, I. inaequale, I. leopoldense, I. subnigrum, I. diversibranchium, I. mariavulcanoae, I. nogueirai, I. beaupertuyi, I. clavibranchium and I. subclavibranchium.

Key words: Neotropical - aquatic insects - black flies - Simuliidae - Inaequalium

The geographic distribution of the genus Inaequalium (Coscarón \& Wygodzinsky, 1984) comprises South and Central America; its northern limit is Panama and to the south it reaches the Pampas region in Argentina, but is not found in Central Amazon. Most species are recorded from the coastal mountains of Brazil (Coscarón \& Wygodzinsky 1984, Coscarón 1987, 1991, Py-Daniel \& Moreira 1989, Strieder et al. 1992, Coscarón \& CoscarónArias 1995, 1997, Strieder \& Py-Daniel 1999, 2000).

Coscarón and Wygodzinsky established the taxon Inaequalium in 1984 as a subgenus of Simulium Latreille, 1802, having Simulium (Inaequalium) inaequale (Paterson \& Shannon, 1927) as the type species. Adults of the eight species initially included in Inaequalium, are black of medium size with wings between 2.3-2.8 mm long; thorax laterally and posteriorly with a gray stripe; cibarium of females with an elevated base in the median area, with conspicuous, well sclerotized spines. Females also present short paraprocts, much wider than long. Males have basistyle with length and width almost equal and longer than the dististyle; dististyle presents a sub-triangular, subquadrate or sub-cylindrical shape and has strong apical or pre-apical spines. Pupae have cocoons with a dorsal length between 2.1-3.8 mm and ventral length between 2.8-4.5 mm; filamentous gills with six terminal filaments ("inaequale" species-group) or thick gills with two to six branches ("botulibranchium" species-group). Larvae present $1+1$

This research received financial support from the Universidade do Vale do Rio dos Sinos, Fapergs, and was partially supported with a grant from MEC/Capes, Brazil, through the Programa Institucional de Aperfeiçoamento de Pessoal de Nível Superior PICDT, and is part of the first author's PhD thesis.

${ }^{+}$Corresponding author. Fax: +55-51-2590.8122. E-mail: strieder@cirrus.unisinos.br

Received 19 January 2001

Accepted 18 September 2001 sub-triangular posterior ventral tubercles; generally deep gular cleft, with a sub-triangular shape or reduced cleft, with a semicircular format (I. souzalopesi); the third article of the antenna in general darker and longer than the first and second (Coscarón \& Wygodzinsky 1984).

According to Py-Daniel (1990) and Py-Daniel and Moreira Sampaio $(1994,1995)$, the recognition and utilization of the levels of subfamily, tribe, genus and subgenus varies in the Simuliidae and that depends on the point of view of the taxonomist. These authors, based on a revision of Nearctic and Neotropical genera originally considered as Prosimuliini and the genus Simulium from Simuliini, proposed to eliminate the tribal level and to elevate all the subgenus of Simulium s.l. to generic rank. Under these circumstances, Simulium Latreille, 1802 would be restricted to Simulium s. str., in the Holarctic Zoogeographical region. Although many taxonomists follows Crosskey and Howard (1997) which maintain the higher classification of Crosskey (1987) and critique Py-Daniel and Moreira Sampaio (1994, 1995) hypothesis. Coscarón et al. (1999) studied the species of Simulium from the Neotropical region, after meticulous phylogenetic studies, these authors concluded that the revised Neotropical species form an independent supraspecific group of Simulium s. str., for which the name Asphatia was suggested.

In this work, the elevation of the subgenus to genus in Simuliidae is followed, according to the nomenclature used by Py-Daniel and Moreira Sampaio (1994, 1995), Py-Daniel (1997), Strieder and Py-Daniel (1999, 2000) and Andrade et al. (2000). Since species of the genus Inaequalium show a homogeneous adult morphology it is necessary to intensify the search for new characters to facilitate recognition and in order to correlate the characters of different stages. The larvae and pupae present features that allow the differentiation of species (Coscarón \& Wygodzinsky 1984, Strieder 1998, Strieder \& Py-Daniel 1999, 2000). The present study provides new characters for recognition of species of Inaequalium and by a comparative analysis of these characters, presents a phylogenetic hypothesis for the genus. 


\section{MATERIALS AND METHODS}

Following Coscarón and Wygodzinsky (1984), Crosskey (1987), Crosskey and Howard (1997), Coscarón (1987, 1991), Py-Daniel and Moreira (1989), Py-Daniel and Moreira Sampaio (1995), Strieder and Py-Daniel (1999, 2000) a preliminary list of the species of simuliids included in the genus Inaequalium (Coscarón \& Wygodzinsky, 1984) was prepared. From the revision of types, the examination of material available in important collections and bibliographic data a matrix of characters was elaborated. New characters that allow a better differentiation of the species were verified. Elaboration of the relationship between the species of Inaequalium was based on the phylogenetic systematics developed by Henning (1966). On the table that originated the data matrix of characters a code for each one was designed, in which the number " 0 " (zero) means hypothetically the plesiomorphic state, the numbers " 1 " (one) and " 2 " (two) indicate the apomorphic state and "?" indicate that the character is not comparable or unknown for the taxon. In the polarization of the characters considered for the elaboration of a phylogenetic hypothesis among the species of Inaequalium, the taxon Cerqueirellum (PyDaniel, 1983), which correspond to a monophyletic group nearly related, was considered as outgroup (Coscarón 1987). Data were analyzed using the Tree Gardener 1.0 program (Ramos 1996), which was developed based on Henning 86 version 1.5 (Farris 1989). The ie* command and implicit enumeration were used for calculating the cladogram. For the majority of the characters there was no distinction or emphasis. However, the character 12 was considered particularly additive. The convergent characters (c) and the reversions (r) are indicated on the cladogram obtained.

Only 15 species of the genus Inaequalium: I. beaupertuyi (Ramírez-Pérez, Rassi \& Ramírez, 1977), I. botulibranchium (Lutz, 1910), I. clavibranchium (Lutz, 1910), I. diversibranchium (Lutz, 1910), I. inaequale (Paterson \& Shannon, 1927), I. leopoldense Strieder \& Py-Daniel, 2000, I. mariavulcanoae (Coscarón \& Wygodzinsky, 1994), I. nahimi (Py-Daniel, 1984), I. nogueirai (D'Andretta \& González, 1962), I. petropoliense (Coscarón, 1980), I. rappae (Py-Daniel \& Coscarón, 1982), I. subclavibranchium (Lutz, 1910), I. subnigrum (Lutz, 1910), I. souzalopesi (Coscarón, 1980) and I. travassosi (D'Andretta \& D'Andretta, 1947) were considered as final taxa in the phylogenetic analysis. The others related species: I. clarki (Fairchild, 1940), I. lurybayae (Smart, 1944), I. parimaensis (Ramírez Pérez, Yarzábal, Takaoka, Tada \& Ramírez, 1986), I. pseudoexiguum (Nunes \& Almeida, 1974), were not included due to their uncertain taxonomic situation and/or insufficient data.

\section{RESULTS AND DISCUSSION}

In the present phylogenetic study 37 characters ( 2 for females, 2 for males, 22 for pupae and 11 for larvae) were used (Table I). Table II shows the basic matrix related to the results of the analysis of the 37 characters considered. Using the program Hennig 86, ie* command, a unique possible cladogram presenting data of the characters considered was obtained. It presents a length of 52 steps, and a CI of 0.76 and RI of 0.81 (Fig. 1).

Cerqueirellum represents a monophyletic taxon sustained by three synapomorphies derived from the morphology of the larva, as follows: setae of cephalic apotome with internal branching; second external teeth of the man- dible absent or extremely reduced; and mandible with a row of setae reaching the supramarginal inferior area. In the resulting cladogram of Inaequalium, the species of the whole internal group are grouped independently of Cerqueirellum, and this shows that these taxa are monophyletic.

The monophyly of the genus Inaequalium is sustained by the following characters: basal portion of female cibarium with small teeth arranged over median prominency (1:1); and third anterior part of distal brush of larval mandible presenting setae with bifurcation near insertion base (36:1). This synapomorphies observed to Inaequalium justify the treatment of this group as genus, instead of subgenus. This is in agreement with Coscarón and Wygodzinsky (1984), Coscarón (1987) and Coscarón and Coscarón-Arias (1997), who concluded that Inaequalium (as a subgenus) form a monophyletic taxon. The cladogram obtained in Inaequalium has two well-defined clades, the "botulibranchium" species-group and the "inaequale" species-group, similar to those of Coscarón (1987) and Coscarón and Coscarón-Arias (1997).

The "botulibranchium" species-group includes $I$. travassosi, I. souzalopesi, I. botulibranchium and I. petropoliense. This clade is defined by three synapomorphies and two convergences: (5:1) texture of pupal gill filaments without reticulate; (6:1) pupae with thick gill branches (c); (17:1) pupal frontoclypeus with multinodulous tubercles; $(25: 1)$ pupal abdomen tergites I and II with spines; and (31:0) larvae without setae on dorsal-posterior region of abdominal cuticle (c). This group has a distribution restricted to the mountains of southeastern Brazil (Fig. 2).

The "inaequale" species-group includes $I$. rappae, $I$. nahimi, I. inaequale, I. leopoldense, I. subnigrum, I. diversibranchium, I. mariavulcanoae, I. nogueirai, I. beaupertuyi, I. clavibranchium and I. subclavibranchium. This group is defined by the following synapomorphies: (23:1) and (23:2) pupa with thorax tubercles wider or as wide as the diameter of the thoracic trichomes at point of insertion; (30:1) larval anal gills with 13 to 20 lobes in each external branch.

This second species-group is also predominantly from the mountains of southeastern Brazil with a larger diversity in the Serra do Mar region, where only I. beaupertuyi and I. nahimi do not occur (Fig. 3). The species $I$. inaequale and I. subnigrum present a large range, covering most of the tropical area of South America, except the lowland region of the Central Amazon. The only two species that are absent from the mountains of southeastern Brazil occur respectively on the Escudo Venezolano and in the southern region of Amazon, restricted to the Mato Grosso in the old western Brazilian shield.

In relation to the two groups obtained in Inaequalium, the results are similar to those presented by Coscarón (1987, 1991) and Coscarón and Coscarón-Arias (1997). The results only disagree with these authors in relation to the position of I. travassosi, which they include in the "inaequale" group.

The first branching of the "botulibranchium" speciesgroup separates I. travassosi from I. souzalopesi subgroup. I. travassosi present a homoplasy: (27:1) antenna of larva smaller than the stem of labral fan (c).

I. souzalopesi subgroup present seven synapomorphies: (2:1) female paraproct basally longer than wide and acuminate on distal half; (3:1) male distimere longer 
than twice its width at base; $(4: 2)$ distimere with subcylindrical shape; (10:1) larval gill with ventral branch curved; (14:1) pupal frontoclypeus and thorax with few tubercles; (29:1) larval cervical sclerites big and fixed on cephalic apotome; and $(33: 1)$ larval hypostomial bridge equal to or bigger than hypostomium.

The characters that separate I. souzalopesi from $I$. botulibranchium and I. petropoliense are the following: (15:1) and (16:1) pupal frontoclypeus with subdivided tubercles and without nodulosity; (18:1) and (24:1) larva with simple cephalic and thoracic trichomes; (28:1) antennal articles of larva with transversal striations.

I. botulibranchium subgroup is defined by a synapomorphy and a homoplasy: (8:1) pupal gill branches with appendages (microfilaments or spines); (22:0) pupae with rounded and subtriangular tubercles (r).
One character of the pupa, (25:0) abdominal tergites I and II without spines (r), characterize I. botulibranchium.

I. petropoliense is characterized by one homoplasy and two autoapomorphies of the pupa, as follows: (14:0) frontoclypeus with abundant tubercles (r); (19:1) antennal sheaths with tubercles; and (21:1) thoracic tubercles subtriangular shaped and with uniform distribution.

The first branching of the "inaequale" group separates I. rappae from the other species.

I. rappae presents a homoplasy and an autopomorphy: (6:1) pupal gill with thick branches (c); (20:1) pupal cephalic genae with trichomes.

One synapomorphy and a homoplasic state: ventral cocoon length almost equal $(12: 1)$ or smaller $(12: 2)$ than length of gill branches supported the monophyly of the species with filiform gills.

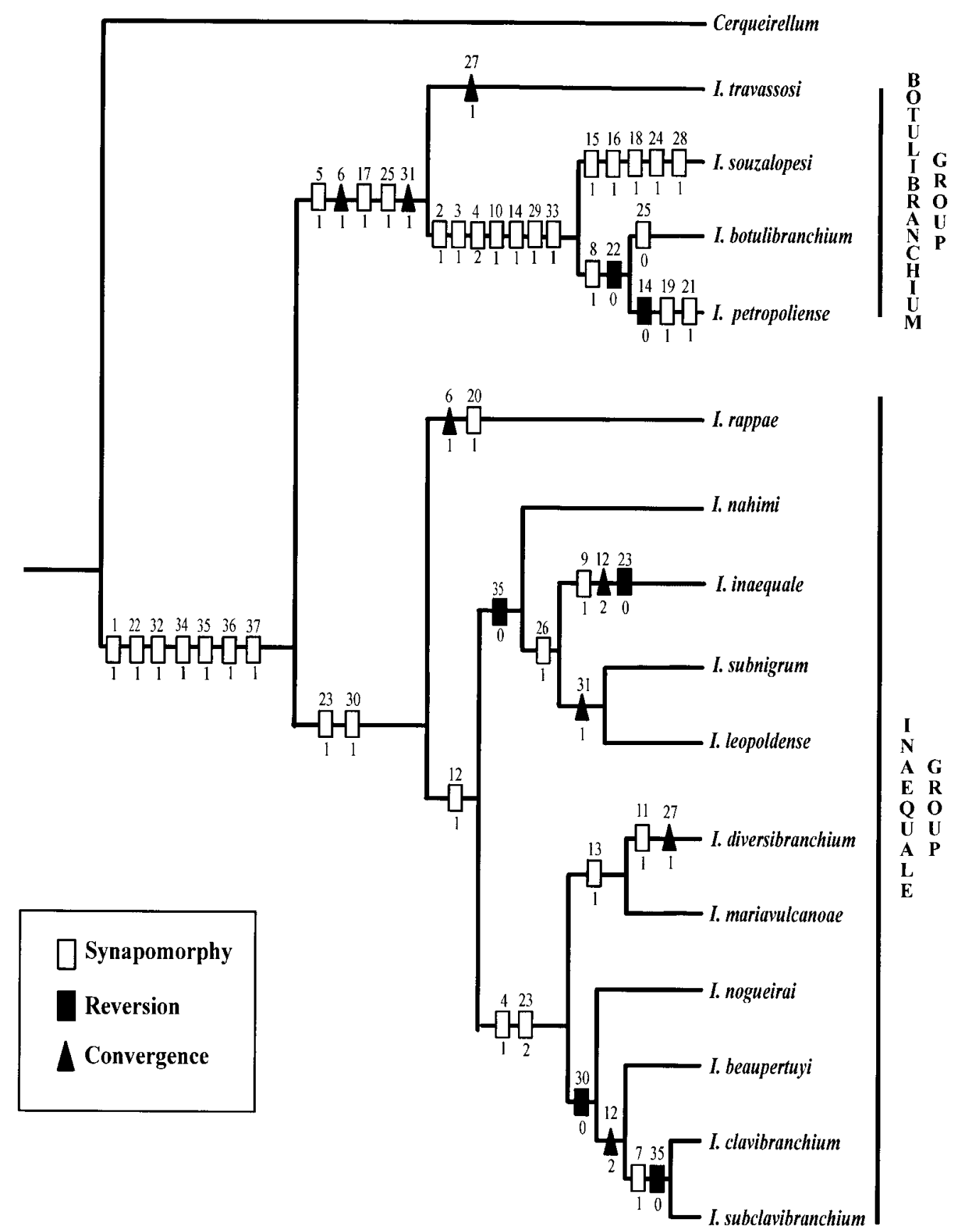

Fig. 1: cladogram of Inaequalium, presenting a length of 52 steps, and a CI of 0.76 and RI of 0.81. Source: Milton Norberto Strieder 
TABLE I

Characters that originated the data matrix and character states used in the phylogenetic analysis of Inaequalium (Coscarón \& Wygodzinsky, 1984)

\section{FEMALES}

1. The basal portion of cibarium shape

(0) With teeth laterally and absent in central depression

(1) With small teeth arranged over median promontory

(?) Unknown

\section{Paraproct size}

(0) Shorter or as long as width at base and almost subtriangular or rounded distally

(1) Basely longer than wide, acuminate on distal half

(?) Unknown

\section{MALES}

3. Proportion between distimere length (DL) and width at base (WB)

(0) DL shorter than twice its WB

(1) DL longer than twice its WB

(?) Unknown

4. Distimere shape
(0) Subtriangular
(1) Subquadrate
(2) Subcylindrical
(?) Unknown

PUPAE

5. Texture of gill filaments with reticulate
(0) Present

(1) Absent

6. Gill branches thickness

(0) Thin and filament-shaped (filiform)

(1) Thick

7. Filiform gill branches distal portion

(0) Not inflated

(1) Inflated

8. Presence of appendages in gill branches (microfilaments or spines)

(0) Without appendages

(1) With appendages

9. Filiform gills with the primary ventral and the two secondary dorsal branches of equal length
(0) Absent
(1) Present
(?) Non-comparable

10. Gill branches (shape)

(0) All branches similar

(1) Ventral branch curved

11. Position of gill branches

(0) All branches directed forward

(2) Terminal ventral gill branches directed backwards

12. Proportion of cocoon length (CL) and gill branches length (GBL)

(0) CL longer than GBL $(1: 1,42-2,81)$

(1) CL almost equal to GBL $(1: 0,90-1,14)$

(2) CL smaller than GBL $(1: 0,63-0,86)$

13. Filiform gills with dorsal primary branch longer or of equal length to ventral primary branch
(0) Absent
(1) Present
(?) Non-comparable

14. Frontoclypeus and thorax tubercles (number)

(0) Abundant

(1) Scarce

15. Frontoclypeus tubercles (shape)

(0) Not subdivided

(1) Subdivided

16. Frontoclypeus tubercles (nodulousity)

(0) Present

(1) Absent

17. Frontoclypeus tubercles (number of nodules)

(0) Only one central

(1) Multinodulous

(?) Non-comparable

18. Facial trichomes (branches)

(0) Simple

(1) Bifid or with more branches 
19. External surface of antennal sheaths

(0) Not covered with tubercles (flat)

(1) Covered with tubercles

20. Genal trichomes

(0) Absent

(1) Present

21. Distribution of tubercles on the frontoclypeus and thorax

(0) Arranged in groups

(1) With uniform distribution

22. Thoracic tubercles (shape)

(0) Rounded and subtriangular

(1) Exclusively rounded

23. Relation between thoracic tubercles wideness and diameter of thoracic trichomes at point of insertion

(0) Tubercles smaller than insertion

(1) Tubercles as wide as the diameter of the thoracic trichomes at the insertion

(2) Tubercles wider than insertion

24. Thoracic trichome shape

(0) Simple

(1) Multiramous (2-7 branches)

25. Abdominal tergites I and II (spines)

(0) Absent

(1) Present

26. Abdominal tergite I (tubercles)

(0) Absent

(1) Present

\section{LARVAE}

27. Proportion between antenna and stem of labral fan

(0) Antenna longer than or equal to stem of labral fan

(1) Antenna smaller than stem of labral fan

(?) Unknown

28. Antennal articles (transversal striations)

(0) Without striations

(1) With striations

(?) Unknown

29. Cervical sclerites

(0) Short, small and free in membrane

(1) Big and fixed on cephalic apotome

(?) Unknown

30. Number of lobes in each external branch of anal gill

(0) From 3 to 12

(1) From 13 to 20

(?) Unknown

31. Setae from the abdominal cuticle on the dorsal-posterior region

(0) Present, many

(1) Absent or few

(?) Unknown

32. Setae of cephalic apotome with internal branching

(0) Present

(1) Absent

(?) Unknown

33. Proportion between length of hypostomial bridge (HIB) and hypostomium (HIP)
(0) HIB smaller than HIP
(1) HIB equal to or bigger than HIP
(?) Unknown

34. Second external teeth of mandible
(0) Absent or extremely reduced
(1) Always present and relatively big
(?) Unknown

35. Lateral mandibular process (shape)

(0) Straight or with slight curve in the middle area

(1) Curved or sinuous

(?) Unknown

36. Third anterior part of distal brush of mandible presenting setae with bifurcation
(0) Near median region
(1) Near basal insertion
(?) Unknown

37. Supramarginal setae of mandible
(0) Present
(1) Absent
(?) Unknown

The character number 12 was considered additive and the others not additive. 


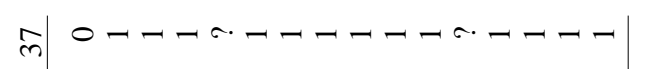

잉

$\approx 0--1+-0000-a-100$

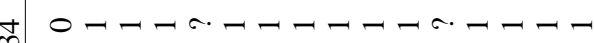

m $00-1.000000 \% 0000$

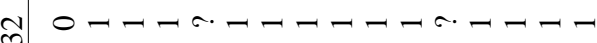

m o-r. - r. $000-100.0000$

ᄋ o or. or. - - - - r. 0000

ते $00-\pi .000000 \pi .0000$

N 00-0r.000000r.0000

त $0-000.00000-\pi .0000$

ㄴ $0000000-1-000000$

च $0-1-0-00000000000$

I $00-0000000000000$

m $00000-70-\pi n N N N N$ N

ป

त $0000-00000000000$

이 $00000-0000000000$

$0000-00000000000$

$00-0000000000000$

I $0-r-1-00000000000$

$00-0000000000000$

$n 00-0000000000000$

I $00-1000000000000$

m or.arar.ar. $000-10000$

a $000000-n-7-7-n n n$

$=0000000000-00000$

$000-7-00000000000$

a or.r.r.r.r.0-00000000

$\infty$

$000-100000000000$

- $00000000000000-1$

$00-1-10000000000$

$n 0-1-100000000000$

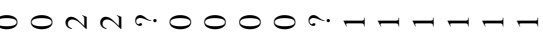

$00-\pi .00000 .00000$

$00-1-0000 \pi .000000$

○ーーーーーーーー๙レーーーーー

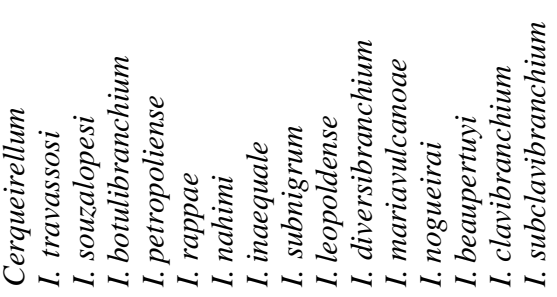

The second branching of the "inaequale" group results in two clades, respectivaly supported with a reversion and two synapomorphies. These two monophyletic groups are composed by four and six species respectively. The homoplasy: (35:0) lateral mandibular process straight or with a slight depression in the middle area (r), is the character which congregates the following species: $I$. nahimi, I. inaequale, I. leopoldense and I. subnigrum. The synapomorphies: (4:1) distimere subquadrate shaped; and $(23: 2)$ pupa with wide thoracic tubercles, relating to the diameter of thoracic trichomes at point of insertion, sustain the monophyly of the following species: $I$. diversibranchium, I. mariavulcanoae, I. nogueirai, I. beaupertuyi, I. clavibranchium and I. subclavibranchium.

The first branching of the first clade of species with filiform gills separates I. nahimi from I. inaequale subgroup.

I. inaequale subgroup is defined for: $(26: 1)$ presenting tubercles in the abdomen tergite I of the pupa. The next branching separates I. inaequale from I. subnigrum and $I$. leopoldense.

I. inaequale presents a synapomorphy and two homoplasies: (9:1) filiform gills with the primary ventral branch and the two secondary dorsal branches generally of the same length; (12:2) cocoon length smaller than the maximum length of the gill filaments (c); and (23:0) pupal thoracic tubercles small, relative to the diameter of the thoracic trichomes at the point of insertion (r).

I. subnigrum and I. leopoldense present a homoplasy: (31:1) setae from abdominal cuticle on the dorsal-posterior region of larva absent or in a reduced number (c).

The first branching of the second clade of species with filiform gills separates $I$. diversibranchium and $I$. mariavulcanoae from I. nogueirai subgroup.

I. diversibranchium and I. mariavulcanoae present a synapomorphy: (13:1) filiform gills with the primary dorsal branch presenting bigger or equal length to ventral primary branch.

The next dichotomy separates I. nogueirai from $I$. beaupertuyi subgroup.

I. beaupertuyi subgroup presents a homoplasy: (12:2) ventral length of cocoon smaller than the maximum length of the gill filament (c).

I. clavibranchium and I. subclavibranchium establish a monophyletic group, apart from I. beaupertuyi by a synapomorphy and a homoplasy: (7:1) gill filaments of pupa with distal portion inflated; (35:0) lateral mandibular process almost straight and not crossing inferior margin of mandible ( $\mathrm{r}$ ).

This work presents a cladistic analysis of the genus Inaequalium (Coscarón \& Wygodzinsky, 1984), which allows the following conclusions to be made: (1) the analysis of 37 characters confirms the existence of two clades morphologically well defined in this taxon. The "botulibranchium" group, which brings together the species: I. travassosi, I. souzalopesi, I. botulibranchium and I. petropoliense; and the "inaequale" group, which brings together the following species: I. rappae, I. nahimi, I. inaequale, I. subnigrum, I. leopoldense, I. diversibranchium, I. mariavulcanoae, I. nogueirai, I. beaupertuyi, I. clavibranchium and I. subclavibranchium; (2) Inaequalium is a monophyletic group, which presents a wide geographic distribution in the Neotropical region occurring predominantly in the coastal region of Brazil, with a larger diversity on the slopes of the Serra do Mar mountain range. 


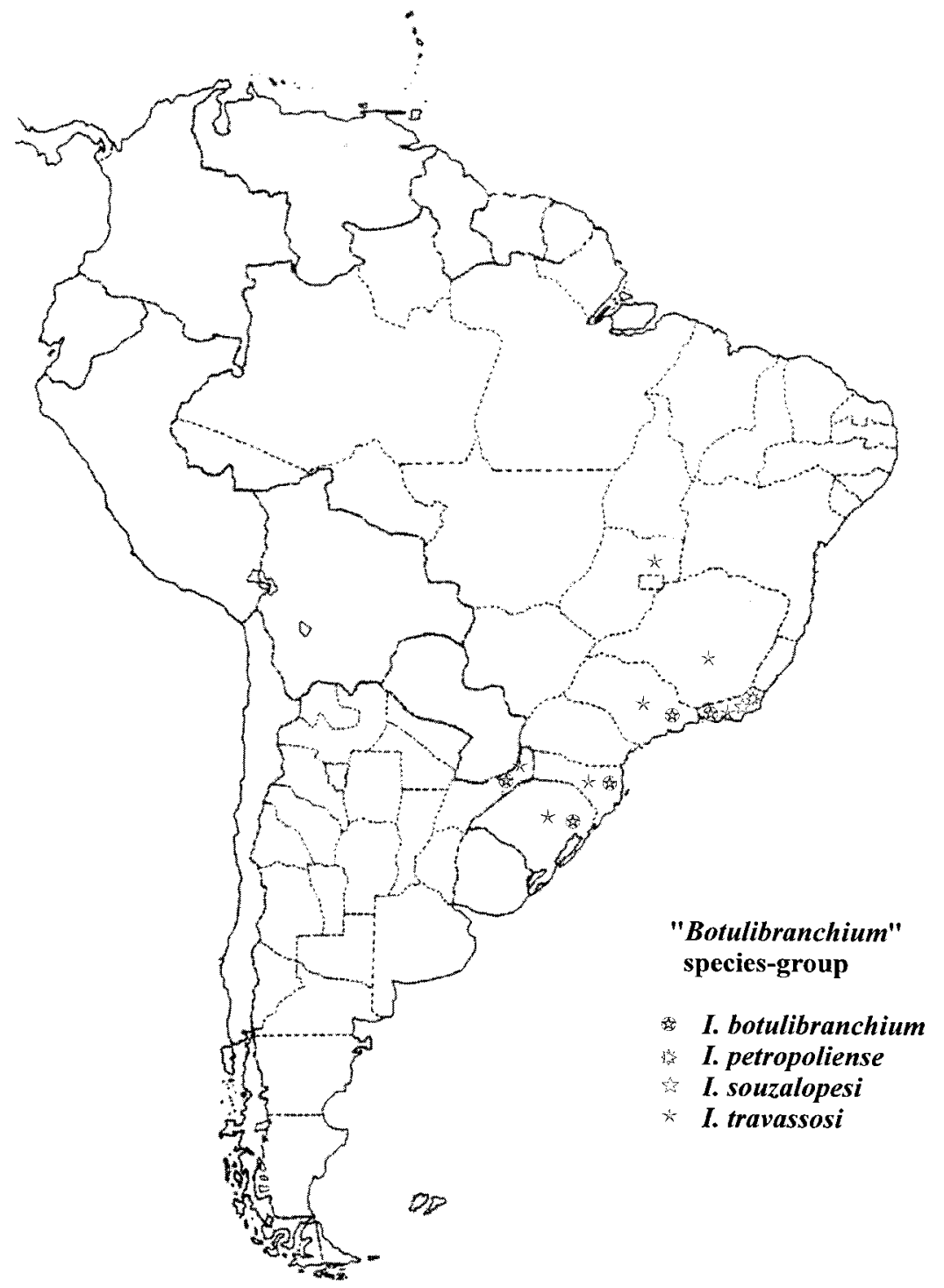

Fig. 2: geographic distribution of species of the "botulibranchium" group. Source: Milton Norberto Strieder

\section{ACKNOWLEDGEMENTS}

To Dr Sixto Coscarón, Universidad Nacional de La Plata, Museo de La Plata, Argentina, for the incentive and for lending specimens; to Dr Cecília Volkmer-Ribeiro, Fundação Zoobotânica do Rio Grande do Sul; Dr Gervásio Silva Carvalho, Pontifícia Universidade Católica do Rio Grande do Sul; Dr Gilson Moreira, Universidade Federal do Rio Grande do Sul for helpful discussions. To Dr Paulo Günter Windisch, Fernando Joner and José Eloy dos Santos Jr, Universidade do Vale do Rio dos Sinos, for reviewing and improving the manuscript.

\section{REFERENCES}

Andrade HTA, Nascimento RSS, Gurgel HCB, Medeiros JF 2000. Simuliidae (Diptera) integrantes da dieta de Poecelia vivipara Bloch \& Schneider, 1901 (Atheriniformes; Poeciliidae) no rio Ceará-Mirim, Estado do Rio Grande do Norte, Brasil. Entomol y Vec 7: 119-122.

Coscarón S 1987. El gênero Simulium Latreille en la Región Neotropical: Análisis de los Grupos Supraespecíficos, Especies que los Integran y Distribución Geográfica (Simuliidae, Diptera), Museu Paraense Emílio Goeldi, Coleção Emilie Snethlage, Belém, Brazil, 111 pp.

Coscarón S 1991. Simuliidae. Fauna de Agua Dulce de la
República Argentina (Insecta, Diptera), Fundación para la Educación, la Ciencia y la Cultura, Buenos Aires, 304 pp.

Coscarón S, Coscarón-Arias CL 1995. Distribution of Neotropical Simuliidae (Insecta, Diptera) and its areas of endemism. Rev Acad Colomb Cienc 19: 717-732.

Coscarón S, Coscarón-Arias CL 1997. Cladistic analysis of the subgenera Inaequalium, Psaroniocompsa, and Chirostilbia of the genus Simulium, with comments on their distribution (Diptera: Simuliidae). Rev Soc Entom Arg 56: 109-121.

Coscarón S, Wygodzinsky P 1984. Notas sobre simúlidos neotropicales. VII. Sobre los subgêneros Psaroniocompsa Enderlein y Inaequalium, subgen. nov. Arq Zool São Paulo 31: 37-103.

Coscarón S, Ibáñez-Bernal S, Coscarón-Arias CL 1999. Revision of Simulium (Simulium) in the Neotropical realm (Insecta: Diptera: Simuliidae). Mem Entomol Internl 14: 543-604.

Crosskey RW 1987. An annotated checklist of the world black flies (Diptera: Simuliidae), Part. VIII, Black fly species of the world. In KC Kim, RW Merritt (eds), Black Flies: Ecology, Population Management, and Annotated World List, University Park: The Pennsylvania State University, p. 425-520.

Crosskey RW, Howard TM 1997. A New Taxonomic and Geographical Inventory of World Blackflies (Diptera: Simuliidae), The Natural History Museum, London, 144 pp. 


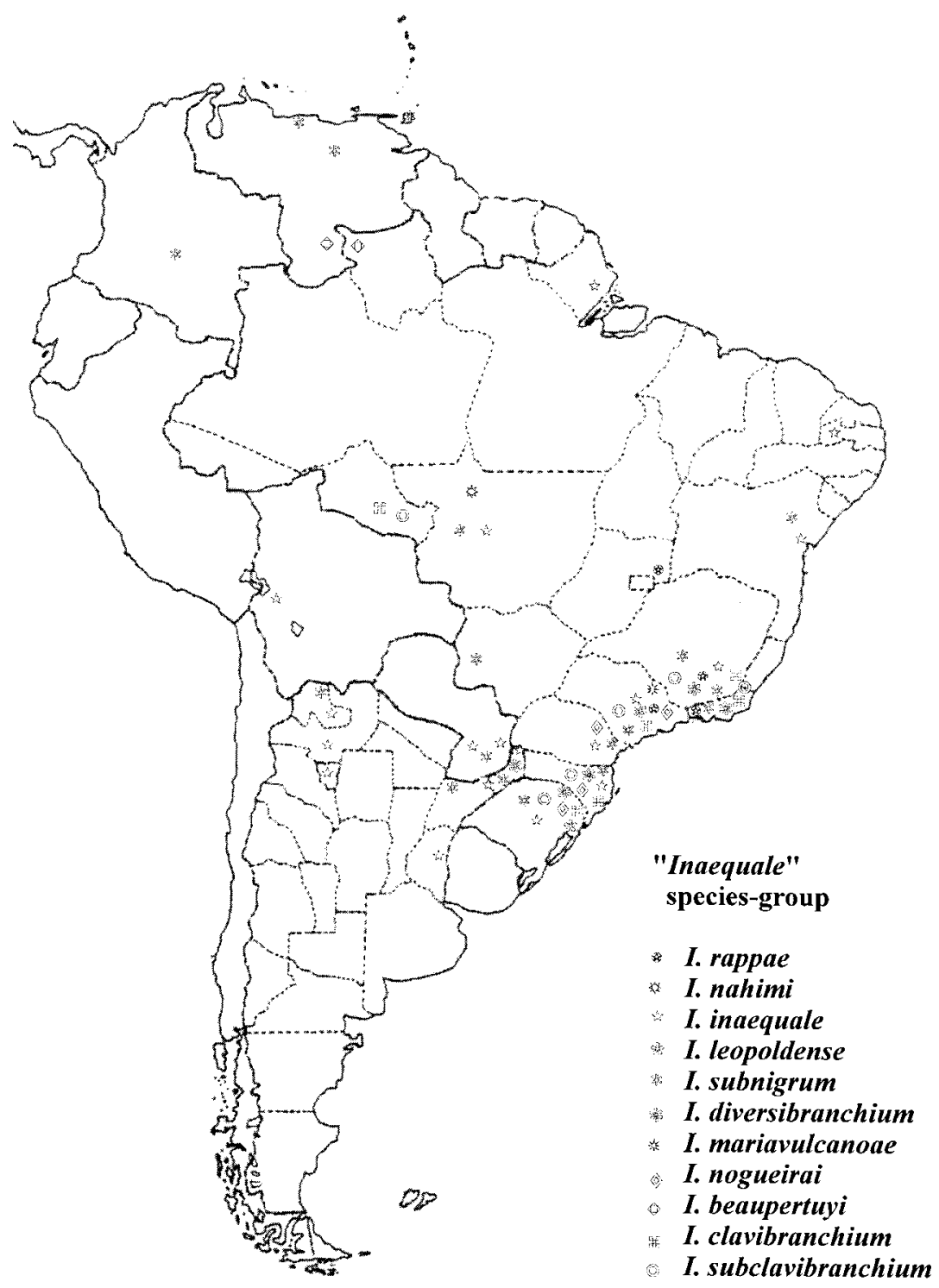

Fig. 3: geographic distribution of species of the "inaequale" group. Source: Milton Norberto Strieder

Farris JS 1989. HENNIG86. A PC-DOS Program for Phylogenetic Analysis. Cladistics 5: 1-163.

Hennig W 1966. Phylogenetic Systematics, University of Illinois Press, Urbana, 263 pp.

Py-Daniel V 1983. Caracterização de dois novos subgêneros em Simuliidae (Diptera: Culicomorpha) Neotropical. Amazoniana 8: 159-223.

Py-Daniel V 1990. Revisão da Tribo Prosimuliini (Diptera: Culicomorpha), Simuliidae nas Regiões Zoogeográficas Neártica e Neotropical (Larvas e Pupas), PhD Thesis, Instituto de Pesquisas da Amazônia, Manaus, 334 pp.

Py-Daniel V 1997. Oncocercose, uma endemia focal no hemisfério norte da Amazônia. In RI Barbosa, EJG Ferreira, EG Castellón (eds), Homem, Ambiente e Ecologia no Estado de Roraima, Inpa, Manaus, p. 111-155.

Py-Daniel V, Moreira GRP 1989. Simuliidae (Diptera, Culicomorpha) no Brasil. IX. Sobre o Simulium (Inaequalium) nogueirai d'Andretta \& González, 1964. Iheringia 69: 8595.

Py-Daniel V, Moreira Sampaio RT 1994. Jalacimgomyia gen.n. (Culicomorpha); a ressurreição de Gymnopaidinae; a eliminação do nível tribal; apresentação de novos caracteres e a redescrição dos estágios larval e pupal de Simulium colombaschense (Fabricius, 1787) (Diptera: Simuliidae). Mem CAICET 4: 101-148.

Py-Daniel V, Moreira Sampaio RT 1995. Gêneros e espécies de Simuliidae (Diptera: Culicomorpha) assinalados para o Brasil até 1995. Entomol y Vec 2: 117-121.

Ramos TC 1996. Tree Gardener version 1.0 software implementation. Distributed by the author.

Strieder MN 1998. Revisão e Análise Cladística de Espécies de Inaequalium (Coscarón \& Wygodzinsky, 1984) (Diptera, Simuliidae), PhD Thesis, Pontifícia Universidade Católica do Rio Grande do Sul, Porto Alegre, 160 pp.

Strieder MN, Py-Daniel V 1999. Espécies de Inaequalium (Diptera, Simuliidae): dados bionômicos e chaves para sua identificação. Biociências 7: 43-72.

Strieder MN, Py-Daniel V 2000. Revisão de Inaequalium (Diptera, Simuliidae), com redescrição das formas imaturas e descrição de uma nova espécie. Entomol y Vec 7 (Suppl. 2): 1-91.

Strieder MN, Corseuil E, Py-Daniel V 1992. Espécies do gênero Simulium (Diptera, Simuliidae) ocorrentes no Rio Grande do Sul, Brasil, com chaves para sua identificação. Acta Biol Leopold 14: 53-74. 